\title{
Nonepitheliotropic lymphoma in a dog: case report
}

\author{
[Linfoma cutâneo não-epiteliotrópico: relato de caso]
}

\section{"Relato de Caso/Case Report"}

\author{
Ellen Cristina Siepmann*, Larissa Yurika Tanabe, Filipe Krasinski Cestari, \\ Juliana Teixeira Druziani, Aline de Marco Viott
}

Universidade Federal do Paraná, Palotina-PR, Brasil.

*Autor para correspondência/Corresponding author: E-mail: ellensiep@gmail.com

\begin{abstract}
Cutaneous lymphoma is an uncommon neoplasm in dogs and Boxer, Shih Tzu, Cocker Spaniel, Basset Hound and Golden Retriever are predisposed breeds. This report describes the case of a 5-year-old mixed-breed female dog presenting ulcerated and fast-growing skin nodules. Initial cytology revealed a poorly differentiated round cell neoplasm. Excision of nodules was performed due to the emergence of new lesions. Histopathological examination was suggestive of histiocytoma. The lesions recurred after one year, and a surgical excision of nodules was performed. An immunohistochemical examination was carried out to refine the diagnosis, revealing positivity for CD3 markers in neoplastic cells and for HLA-DR in neoplastic lymphoid and reactive histiocytic cells; these findings, coupled with the morphological findings, were compatible with nonepitheliotropic cutaneous T-cell lymphoma. Its etiology has not yet been fully elucidated; however, recurrent skin inflammation may be a predisposing factor, which leads to chronic lymphocytic proliferation. Cutaneous lymphoma (CL) causes nonspecific lesions and its classification as epitheliotropic and nonepitheliotropic (NEL) throughout cutaneous signs is difficult, with NEL being the least described form. Animals affected by this form of lymphoma have lymphadenomegaly, firm and multiple nodules that can extend from the dermis to the subcutaneous layer, alopecic and/or ulcerated, often in chest, head and extremities, with rapid progression, which was compatible with the present case. Definitive diagnosis of CL is obtained through histopathology and immunohistochemistry. The aim is to report a case of nonepitheliotropic cutaneous lymphoma in a dog, with emphasis on its clinical, histopathological, and immunohistochemical aspects.
\end{abstract}

Keywords: cutaneous neoplasms; histology; immunohistochemistry; oncology; dermatology.

\section{Resumo}

O linfoma cutâneo (LC) é uma neoplasia incomum em cães, com predisposição nas raças Boxer, Shih Tzu, Cocker Spaniel, Basset Hound e Golden Retriever. Este relato descreve o caso de uma cadela sem raça definida de cinco anos de idade, apresentando nódulos cutâneos ulcerados e de crescimento rápido. A citologia inicial sugeriu neoplasia de células redondas pouco diferenciada. O exame histopatológico foi sugestivo de histiocitoma. As lesões recidivaram, optando-se então pela excisão cirúrgica dos nódulos e encaminhamento para exame de imunohistoquímica, onde observou-se positividade para os marcadores CD3 nas células neoplásicas e HLA-DR em células linfoides neoplásicas e histiocíticas reativas; estes achados, somados aos achados morfológicos, foram compatíveis com linfoma cutâneo de células T não epiteliotrópico (LCNE). A sua etiologia ainda não foi bem definida, entretanto, a inflamação recorrente da pele pode ser um fator predisponente, pois gera proliferação linfocítica crônica. O LC causa lesões inespecíficas e a sua classificação em epiteliotrópico e não-epiteliotrópico por meio dos sinais cutâneos é difícil, sendo o LCNE a forma menos descrita. Animais acometidos por essa forma apresentam linfoadenomegalia, nódulos firmes e múltiplos que podem se estender da derme ao subcutâneo, alopécicos e/ou ulcerados, frequentemente em tronco, cabeça e extremidades, com rápida progressão, o que foi compatível com o presente caso. O diagnóstico definitivo do 
LC é obtido por meio da histopatologia e imunohistoquímica. O objetivo deste trabalho é relatar um caso de linfoma cutâneo não-epiteliotrópico em um cão, com ênfase em seus aspectos clínicos, histopatológicos e imunohistoquímicos.

Palavras-chave: neoplasias cutâneas; histologia; imunohistoquímica; oncologia; dermatologia.

\section{Introduction}

With the increase in life expectancy and greater attention to the health and welfare of domestic animals, the prevalence of neoplasia is growing and represents one of the main causes of death (Michell, 1999). Due to its complex structure, extension and greater exposure, the skin is considered the most common site for the development of neoplasms (Withrow, 2007).

Lymphoma is a primary neoplasm that involves lymphocytes and can be classified according to the anatomical location, occurring in multicentric, mediastinal, alimentary, and extranodal forms. Cutaneous lymphoma can be originated from B- or T-cells, being named epitheliotropic lymphoma (EL) and nonepitheliotropic lymphoma (NEL) (Valli, 2017). The NEL is a more aggressive and less common form (Fournel-Fleury et al., 2002).

The lesion characteristics and clinical signs are extremely variable (Fontaine et al., 2009; Nelson, 2015). The main macroscopic changes are local or generalized exfoliative erythroderma, plaques, and nodules associated or not with alopecia, crusts, and ulceration (Raskin e Meyer, 2003; Fontaine et al., 2009; Nelson e Couto, 2015). The treatment varies according to the location. Radiotherapy and surgical excision are usually effective against focal masses; however, protocols using chemotherapeutics are more commonly used (Morris, 2007).

The present aim is to report a case of nonepitheliotropic cutaneous lymphoma in a dog, with emphasis on its clinical, histopathological and immunohistochemical aspects.

\section{Description of the Case}

A 5-year-old mixed-breed female dog was examined due to the appearance of fast-growing cutaneous nodules and ulceration, in addition to alopecia in the lumbosacral region. Physical examination revealed ulcerated nodules in the axillary and inguinal region, mild widespread lymphadenomegaly, and hyperthermia. Fine needle aspiration cytology (FNAC) revealed a large population of markedly pleomorphic round cells with a scant-to-moderate bluish cytoplasm, large nuclei and loose chromatin, as well as large numbers of bacterial colonies, neutrophils, and erythrocytes. The findings were suggestive of undifferentiated round cell neoplasia. Treatment with nonsteroidal anti-inflammatory and antibiotic drugs was performed, decreasing the tumor size.

In the reassessment, the patient had an ulcerated, fragile and erythematous skin nodule on the right thoracic limb, and firm and nonulcerated skin nodules on the head and chest. Surgical excision was performed on the nodules of the head and chest, and incisional biopsy of the thoracic limb tumor. Histologically, a highly cellular, poorly delimited, unencapsulated, neoplastic proliferation of round cells of infiltrative growth into the dermis was observed (Figure 1A), not invading epithelial structures such as the hair follicle (Figure 1B). Cells were arranged in mantle, with a scant-to-moderate eosinophilic cytoplasm, reniform nuclei, and coarsely clumped chromatin, with up to two large nucleoli per nucleus (Figure 2). There was mild cellular and nuclear pleomorphism, anisocytosis, anisokaryosis, and mitotic figures were rare. Tumor stroma consisted of a discrete loose connective tissue. Multifocal invasion of blood vessels by neoplastic cells was noted. The findings were suggestive of cutaneous malignant histiocytosis and the owner did not authorize any treatment.

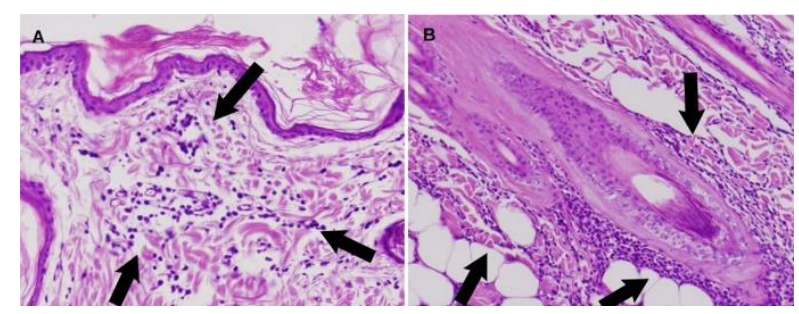

Figure 1. Nonepitheliotropic cutaneous T-cell lymphoma. Hematoxylin and eosin stain (A) 20X. There are neoplastic lymphocytes disposed in mantle, restrict to the dermis, non-encapsulated (arrows). (B) 15X. Neoplastic cells do not invade the hair follicles (arrows) or other epithelial structures.

After one year, lesions similar to those previously described appeared again. Fine needle aspiration cytology revealed findings compatible with a chronic inflammatory process. The biopsy 
indicated neoplastic proliferation of round cells with characteristics similar to those previously described, extending from the stratum lucidum of the epidermis to the subcutaneous musculature. There were three to twelve atypical mitotic figures per high-power field. The findings were compatible with undifferentiated round cell neoplasia, but the main differential diagnoses were cutaneous malignant histiocytosis and nonepitheliotropic cutaneous lymphoma. Immunohistochemistry (IHC) was performed to determine the cellular origin of the neoplasia after nodulectomy.

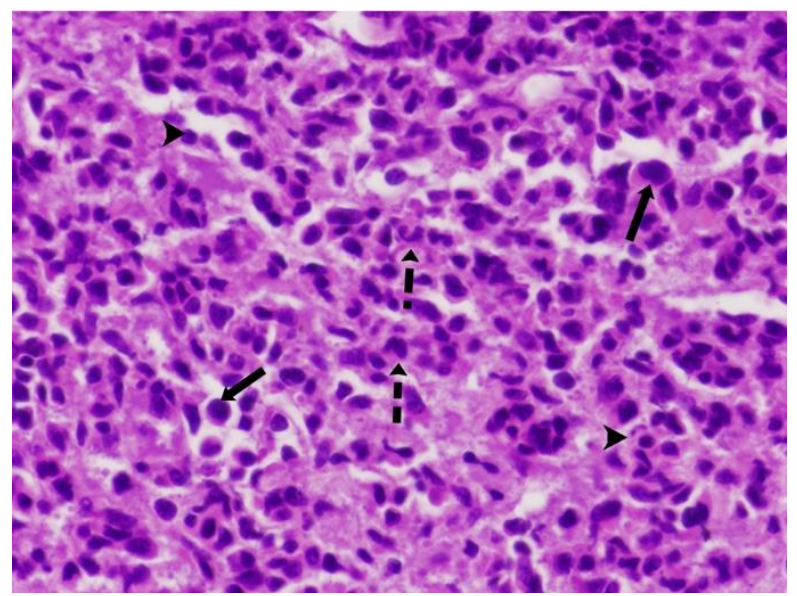

Figure 2. 46X. Nonepitheliotropic cutaneous T-cell lymphoma. Hematoxylin and eosin stain. There is marked pleomorphism of the neoplastic cells. There are neoplastic lymphocytes with large, eosinophilic cytoplasm, big nuclei and loose chromatin (arrows), others with kidney-shaped nuclei (dashed arrows) and yet morphologically normal lymphocytes (arrow heads).

Immunohistochemistry profile was positive for CD3 and HLA-DR markers in neoplastic lymphoid and reactive histiocytic cells. Ki-67 marker (cell proliferation antigen) had shown nuclear positivity less than $5 \%$ between neoplastic cells. CD20, CD45RA and E Cadherin markers were negative. The morphological analysis and the immunohistochemical profile corroborated the diagnosis of nonepitheliotropic cutaneous T-cell lymphoma. Due to the worsening of clinical signs, the owner opted for euthanasia, choosing not to perform necropsy.

\section{Discussion}

Cutaneous lymphoma accounts for approximately $1 \%$ of skin tumors and nearly $3 \%$ to $8 \%$ of all types of lymphoma in dogs (Fontaine et al., 2009). It mainly affects Boxer, Shih Tzu, Cocker Spaniel, Basset Hound and Golden
Retriever breeds (Nelson e Couto, 2015). There is no gender predisposition (Vail, 2011), but some authors mention that female hormones play an important role in the non-development of the disease. This type of lymphoma is classically classified as epitheliotropic or nonepitheliotropic.

Epitheliotropic cutaneous T-cell lymphoma is also known as mycosis fungoides. It has great tropism for epidermis and their attachments, but neoplastic cells can also be observed in the dermis (Moore, 2013). The presence of multifocal aggregates of neoplastic lymphocytes in the epidermis is characteristic of this neoplasm (Pautrier's microabscesses). Neoplastic lymphocytes are positive for CD8 and mitoses are rare. Also, nonepitheliotropic cutaneous T-cell lymphoma is characterized by the infiltration of large atypical lymphocytes into the dermis, which may extend to the subcutaneous musculature, with marked expression of CD3 by immunohistochemistry (Valli, 2017). However, there are cases where $\mathrm{CD} 3$ expression is decreased or the cell population is heterogeneous, making diagnosis difficult. The regions most affected are extremities, face, neck, and chest. Macroscopic lesions are nonpruritic plaques and nodules that are often ulcerated. Histologically, there is a predominance of small and large lymphocytes, commonly associated with infiltration of histiocytes without atypia and are preferentially located in perivascular areas. Neoplastic lymphocytes have large nuclei with loose chromatin. There are one to four mitoses per 400x field. There may be neutrophils, plasma cells and eosinophils in the midst of the neoplasia, which characterizes it as "inflamed". Immunohistochemistry was positive for $\mathrm{CD} 3$ in neoplastic lymphocytes, and intensity may vary depending on the degree of cell atypia. The most atypical lymphocytes and associated histiocytes also express CD18 and CD45. The presence of reactive histiocytes may lead to an erroneous diagnosis of a cutaneous reactive histiocytosis, histiocytoma, or granulomatous dermatitis. The main aspect to be considered for exclusion of these diagnoses is the presence of atypical lymphocyte groups with variable positivity for CD3 (Moore, 2013). These lymphocyte groups were not observed in the histological samples of the reported case; however, the other clinical and morphological aspects corroborate the diagnosis of an inflamed nonepitheliotropic T-cell lymphoma. 
The etiology of NEL has not been completely elucidated. However, the chronic inflammation of the skin as a predisposing factor in dogs is largely discussed, usually associated with atopic dermatitis (Santoro et al., 2007) due to the chronic stimulus for activation and proliferation of lymphocytes (Fontaine et al., 2009). A retrospective study demonstrated that atopic animals are 12 times more likely to develop cutaneous lymphoma when compared to nonatopic animals (Santoro et al., 2007). Alopecia in the lumbosacral region observed in the patient may be suggestive of flea allergy dermatitis, which also leads to chronic lymphocytic proliferation.

Usually, animals affected by NEL usually present lymphadenomegaly and multiple firm cutaneous nodules that can extend from the dermis to the subcutaneous layer, that are alopecic and/or ulcerated, often in the chest, head, and extremities, as observed in the present report (Fontaine et al., 2009). In addition, nodules were found in the dorsal, abdominal, and axillary regions. The progression of lesions tends to occur rapidly (Moore, 1994) and aggressively as observed in this animal.

Once the cytology may be inconclusive in demonstrating the presence of round cells and do not reveal the occurrence of atypical lymphocytes beyond not providing data about the epitheliotropism, the diagnosis of CL is performed by histopathology (Fontaine et al., 2009).

The biological behavior and response to therapy are directly related to the classification of the neoplasm (Fournel-Fleury et al., 2002). Hence, defining the immunophenotype is extremely important for the determination of diagnosis and prognosis. The presence of CD3 and HLA-DR markers indicate that lymphoma was most likely of T-cell origin. Ki-67 indicates high tumor malignancy, therefore the lymphoma in this report could be considered of low-grade malignancy, due to the finding of a nuclear positivity lower than $5 \%$ in neoplastic cells, information corroborated by the survival of the patient after the first diagnosis. Although CL is thought to be chemoresponsive in the dog (Macewan, 1990), dogs with T-cell lymphomas had shorter progression-free and survival times and reduced responsiveness to treatment compared to dogs with B-cell lymphoma (Dobson et al., 2001).

Canine cutaneous lymphoma involving $\mathrm{T}$ cells has a worse prognosis, so early diagnosis is of crucial importance for the rapid determination of the most appropriate treatment, even if the remission rates are known to be varied. In this sense, immunohistochemistry is an indispensable tool to determine the correct diagnosis and definition of the prognosis since it is a neoplasm of difficult classification and clinical-pathological diagnosis.

\section{Conflict of Interest}

The authors declare no conflict of interest.

\section{References}

Dobson, J.M.; Blackwood, L.B.; McInnes, E.F.; Bostock, D.E.; Nicholls, P.; Hoather, T.M.; Tom, B.D.M. Prognostic variables in canine multicentric lymphossarcoma. Journal of Small Animal Practice, 42: 377-384, 2001.

Fontaine, J.; Bovens, C.; Bettenay, S.; Mueller, R.S. Canine cutaneous epitheliotropic T-cell lymphoma: a review. Veterinary and Comparative Oncology, 7: 1-14, 2009.

Fournel-Fleury, C.; Ponce, F.; Felman, P.; Blavier, A.; Bonnefont, C.; Chabanne, L.; Marchal, T.; Cadore, J.L.; Goy-Thollot, I.; Ledieu, D.; Ghernati, I.; Magnol, J.P. Canine T-cell Lymphoma: a morphological, immunological, and clinical study of 46 new cases. Veterinary Pathology, 32: 92-109, 2002.

Ledieu, D.; Ghernati, I.; Magnol, J.P. Canine T-cell Lymphoma: a morphological, immunological, and clinical study of 46 new cases. Veterinary Pathology, 32: 92-109, 2002.

Macewan, E.G. Spontaneous tumours in dogs and cats: models for study of cancer biology and treatment. Cancer and Metastasis Reviews, 9: 125-136, 1990.

Michell, A.R. Longevity of British breeds of dog and its relationships with sex, size, cardiovascular variables and disease. Veterinary Records, 27: 625-629, 1999.

Moore, P.F.; Olivry, T. Cutaneous lymphomas in companion animals. Clinics in Dermatology, 12: 499-505, 1994.

Moore, P.F.; Affolter, V.K.; Keller, M. Canine inflamed nonepitheliotropic cutaneous T-cell lymphoma: A diagnostic conundrum. Veterinary Dermatology, 24(1), 2013. 218p.

Morris, J.; Dobson, J. Small animal oncology. $1^{\text {st }}$ ed. Oxford: Blackwell Science, 2001.

Morris, J.; Dobson, J. Oncologia em pequenos animais. São Paulo: Roca, 2007. 300p. 
Nelson, R.W.; Couto, C.G. Medicina interna de pequenos animais. $5^{\text {a }}$ ed. Rio de Janeiro: Mosby-Elsevier, 2015. 1084p.

Raskin, R.E.; Meyer, D.J. Atlas de citologia de cães e gatos. São Paulo: Roca, 2003. 354p.

Santoro, D.; Marsella, R.; Hernandez, J. Investigation on the association between atopic dermatitis and the development of mycosis fungoides in dogs: a retrospective case-control study. Veterinary Dermatology, 18(2): 101-106, 2007.

Vail, D.M. Tumors of the haemopoietic system. In: Dobson, J.M.; Lascelles, B.D.X. BSAVA
Manual of canine and feline oncology. $3^{\text {rd }}$. ed. Quedgeley: British Small Animal Veterinary Association, 2011. 364p.

Valli, V.E.; Bienzle, D.; Meuten, D.J. Tumors of the Hemolymphatic System. In: Meuten, D.J. (Ed.). Tumors in domestic animals. $5^{\text {th }}$ ed. Ames: Wiley Blackwell, 2017. Cap. 7: 211$329 \mathrm{p}$.

Withrow, S.J.; Vail, D.M. Small animal clinical oncology. $4^{\text {th }}$ ed. Canada: Saunders-Elsevier, 2007. p.995-1002. 